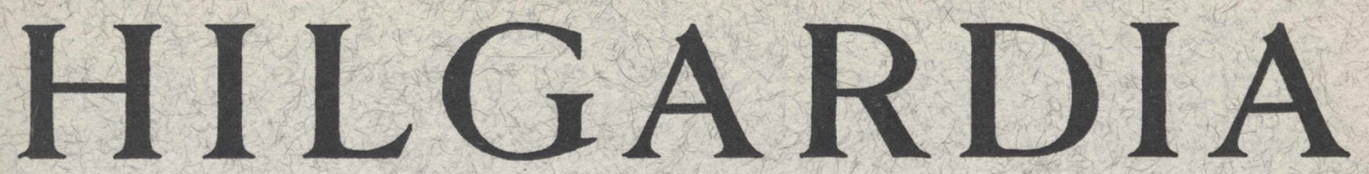

A Journal of Agricultural Science Publisbed by the California Agricultural Experiment Station

\title{
BIOLOGICAL STUDIES OF TWO SPECIES OF TYDEID MITES FROM CALIFORNIA
}

\author{
CLIVE DESMOND BRICKHILL
}

UNIVERSITY OF CALIFORNIA - BERKELEY, CALIFORNIA 
Tydeid mites are commonly present on vegetation, but have been studied very little. This paper mainly concerns possible sources of nutrition of two species of California tydeids, Tydeus bakeri and Lorryia ferulus, of which the former is described in this paper. Further information is given on general biology, on the various nymphal stages, and on possible economic significance. 


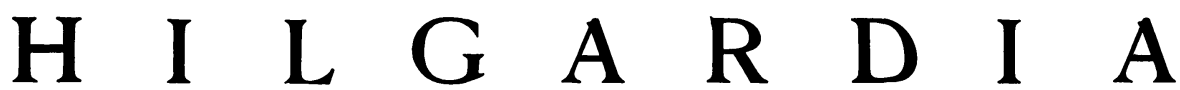

A Journal of Agricultural Science Published by

the California Agricultural Experiment Station

VOL. 27

OCTOBER, 1958

No. 20

\section{BIOLOGICAL STUDIES OF TWO SPECIES OF TYDEID MITES FROM CALIFORNIA ${ }^{1}$}

\section{CLIVE DESMOND BRICKHILL ${ }^{2}$}

\section{INTRODUCTION}

Mites of The family Tydeidae are active mites, frequently found on vegetation. Their bodies are often ovate, generally whitish, and very small, averaging about $250 \mu$ in length. They are not believed to be of economic importance, and little is known of their biology. According to Baker and Wharton $(1952)^{3}$, they appear to be predacious on small insects and mites and their eggs. However, some species may be plant feeders.

Baker and Wharton (1952) state that Tydeus californicus (Banks) is predacious on the citrus bud mite, Aceria sheldoni (Ewing), in southern California. They further remark that Pronematus ubiquitus (McGregor) is common in California on fig trees where it preys on the fig mite, Aceria ficus (Cotte). McGregor (1932) states that P. ubiquitus is not phytophagous, but that its food consists of other insects on the foliage. He adds that the question as to whether this mite functions as a predator or as a scavenger has been a rather difficult matter to determine. The occasional finding of this mite under mature reproducing scales at first encouraged the belief that it might be a true predator. Through lack of sufficient evidence, however, the conclusion was reached that the ubiquitus mite confines its feeding chiefly to the dead bodies of insects and to lifeless eggs. McGregor further states that various other species of Tydeus have been credited with being predatory on scale insects and their eggs. Among these are T. gloveri Ashmead and T. coccophagus Ewing. Ashmead believed that the former feeds on eggs of Lepidosaphes becki (Newman), while the latter species is reported to be of some importance as an enemy of the oystershell scale, $L$. ulmi (Linné), in Iowa.

Fleschner and Arakawa (1952) state that Tydeus californicus feeds and reproduces on avocado leaves free of fungus, insects, or other mites. Careful observation showed that immediately after hatching, the young mites settle down to feed on the leaf surface. There was no obvious feeding injury even though the mites were present in large numbers. They state further

\footnotetext{
${ }^{1}$ Submitted for publication March 5, 1958.

2 Research Assistant in Department of Entomology and Parasitology, Berkeley.

${ }^{3}$ See "Literature Cited" for citations referred to in the text by author and date.
} 
that $T$. californicus must not be assumed to be harmless to the trees simply because it does not produce obvious feeding injury. On the contrary, since this mite feeds on the leaves and often occurs in numbers well over 100 per leaf it must be suspected as a possible pest until proved otherwise. Smirnoff (1957) reports that a species of Lorryia is phytophagous on citrus in Morocco, and may prove to be of economic importance. It feeds usually on the honeydew given off by Saissetia oleae (Bernard), and during development it may become phytophagous. Infestation of an orchard usually progresses swiftly, three to five months sometimes being sufficient for the mite to be distributed over the orchard. In 1956, dense infestation coincided with an abundant honeydew discharge. In colonies of Lorryia, Smirnoff said, egg laying starts on the lower parts of the leaves. Larvae remain until the first molt, then migrate to other trees. At the end of July, the mites are on the young fruit, where they lay eggs. They shelter under the sepals and peduncles and prick and suck the tissues of the young fruit. A ring of dead brown tissue occurs, enlarging as the fruit grows.

Tydeus molestus (Moniez), according to Baker and Wharton (1952), has been reported attacking man in Belgium. They cause irritation by biting human beings and domestic animals, but can be regarded as a minor pest.

\section{THE EXPERIMENTAL TYDEIDS}

A biological study was made of two species of tydeids found in California. No information concerning the biology and ecology of these species has ever been recorded.

Lorryia ferulus Baker was found on a wide variety of hosts in central California: strawberries, walnuts, alfalfa, pyracantha, live oak, Bermudagrass, and eugenia. It usually was found in close association with coccid scales. On eugenia the scale was Saissetia hemisphaerica (Targioni). On live oak the scale was Lecanium quercitronis Fitch. On pyracantha it was Saissetia oleae (Bernard), while on walnut three scales were in association, Lecanium pruinosum Coquillet, Lecanium corni Bouché, and Lecanium cerasorum Cockerell.

Tydeus bakeri $\mathrm{n}$. sp., the second species studied, was found in California at one location only, Albany, on eugenia. It was closely associated with Saissetia hemisphaerica and with Lorryia ferulus, but greatly outnumbered the latter.

Both species of tydeids were observed on leaves or twigs under dead mature scales that had loosened sufficiently for them to crawl under the shield. They were not found under the immature stages of healthy scales nor nesting under live scales bearing maturing eggs. Where honeydew had been voided by the scales, the mites were observed under dried crusts of honeydew which supported sooty mold. The colonies were usually located on the ventral surface of the leaf, primarily in relation to leaf hairs and junction of veins, and to honeydew or to scales. Mite eggs were located often under scales; also they were found lying near the edge of a flake of dry honeydew, between the flake and the leaf surface. On walnuts, eggs were 
common near the junctions of veins on the ventral surface among the leaf hairs. All stages were present in the nesting sites. A scale sometimes harbored 10 or more tydeids and numerous cast skins. Both species of tydeids displayed a strong thigmotactic response, therefore, in oviposition and in nesting sites for the colonies.

When disturbed, the mites moved quickly over the leaf, always returning to the shelter of honeydew, seales, or hairs. Occasionally they were observed moving over honeydew, apparently probing at it through the sooty mold. In the laboratory they were observed similarly active on leaves, as though they were probing the tissues. Despite the presence of heavy populations, no damage to the leaves or other plant parts was observed.

All stages of tydeids of both species were found throughout the year. In winter, as could be expected, there was little activity. In spring, colonies developed rapidly when the scales exuded copious amounts of honeydew. In summer, with the onset of higher temperatures, development slowed, although honeydew was still present in quantity. In fall, populations increased again.

Colonies continued to grow during periods when scale eggs were not present. The belief that tydeids are entirely predacious cannot be accepted freely from observation in the field. On the other hand, other nutrition is available on walnuts when European red mite and two-spotted mite eggs are present, and on strawberries when two-spotted spider mite eggs may be present. Neither of the tydeids was observed in association with eriophyid mites at any time.

\section{COLLECTING TECHNIQUE}

The simplest and most effective method of collection was direct transfer of the mites by brush from leaves or twigs to the rearing substrate. A stereoscopic microscope was used in the work. This required care and concentration because of the small size of the mites and their susceptibility to injury. The brush consisted of six hairs. This method was economical when the supply of mites was limited. With the Berlese funnel method only about half of the tydeids available would appear in the water at the bottom of the funnel and there was considerable mortality.

\section{REARING TECHNIQUE}

In the first rearing method tried, mites were placed on a leaf which rested on damp cotton wool in a petri dish. This method was discarded because of the difficulty of keeping the mites on the leaf. Another method was the use of cells cut in plexiglass. This was discarded because of high mite mortality.

The most satisfactory method was to place the mites on a leaf or on waxed paper floating in water in a stender dish approximately 2 inches in diameter. The size of the waxed paper was $1 / 4 \times 1 / 4$ inch. Because the mites were white, the paper first was blackened with India ink before it was dipped in wax. This method provided a suitable humidity for the mites and a source of water. Although the mites were often seen on the substrate edge, apparently in the process of taking up water, they usually remained on the sub- 
strate. When caught in the water they remained alive for a day or two and could be transferred back to the substrate. This method had the advantage of easy examination of colonies by microscope. A disadvantage was the high humidity which was suitable for fungus growth. This was kept to a minimum by leaving the stender dishes open. Water was added twice a week.

To meet the necessity of providing oviposition sites for the tydeids on the waxed paper substrate, a finely cut splinter of boxwood was added to each substrate when tests using eggs as food were carried out. When dried honeydew was used, this in itself served as an oviposition site. Leaves possessed natural sites along veins, and in any concentration of hairs. In early tests fine kapok, as described by Finney (1953), was dusted onto the substrate. This was discontinued as it was difficult to see the white mites against the similarly colored background.

Rearing was carried out on a table in a room of fairly even temperature, varying from 18 to $20^{\circ} \mathrm{C}$ in winter and 25 to $28^{\circ} \mathrm{C}$ in summer.

\section{NUTRITIONAL EXPERIMENTS}

Without Food. When 10 adult mites of Tydeus bakeri were placed in a small glass dish without access to water, they remained alive for only two to four days. When 10 adults of $T$. bakeri were placed on waxed paper but with water available, they remained alive for a much longer period of time. In one experiment, $10 \mathrm{~T}$. bakeri adults died progressively, the last mite dying on the sixteenth day. No eggs were laid. In another test with 10 adults of the same species, only two adults were alive after two weeks, one adult lasting another week. In this case an egg was laid, which hatched, and the larva remained alive for 17 days, without proceeding to the protonymph stage. Ten adult mites of Lorryia ferulus lived 25 days before the last mite died. Within 12 days eggs had been laid that hatched, and the larvae lived for approximately 19 days, not progressing to protonymphs.

With Leaves Only. Twenty Tydeus bakeri adults were placed on an abelia leaf floating in a stender dish. Abelia was selected because of the long life of its leaves under such conditions. The mites were all dead at the end of 25 days, no eggs being laid. In a similar test with 18 adults the last adult died after 27 days, and three larvae appeared, which did not progress to protonymphs. In a third test of the same species of mite a eugenia leaf was used as well as an abelia leaf. On each leaf approximately half the adults had died after 12 days. After 20 days one mite was alive on eugenia and four still alive on abelia. All had died on eugenia after 23 days, and on the twenty-ninth day the last died on the abelia leaf.

With Lorryia ferulus a similar experiment was set up with 10 adult mites each on eugenia and abelia. After 24 days, all the mites on the eugenia leaf had died, whereas on abelia they lived another three days. Several eggs were laid on each leaf, which hatched; but none of the larvae developed to the next instar.

It is obvious that if nourishment was obtained from the plant cells it was insufficient for the larvae to develop to the protonymph stage, even though they were observed apparently probing the cells. 
To determine if anything was being taken up from plant cells by the mites, a short experiment was carried out using radioactive glycine $-2 \mathrm{C}^{14}$. The stem of an abelia twig bearing three small leaves was placed in a small tube containing two mls of a $10^{-3}$ molar solution of radioactive glycine $1 \mu$ curie $/ \mu$ mole specific activity. Using a fan to keep a constant flow of air over the leaf surface, $1.35 \mathrm{mls}$ of liquid were transpired through the leaves in 37 hours, each leaf surface area being approximately eight square cms. Mites of each species were placed on the leaves floating in stender dishes and allowed to stay for 48 hours. The mites were then lightly crushed onto a thin vaseline smear in the center of a planchet. Seventeen adults of Lorryia ferulus and 13 of Tydeus bakeri were thus examined for radioactivity, as well as a leaf section of $20 \mathrm{sq} \mathrm{mms}$ area.

Counts per minute above background on the Tracerlab SC-1C Autoscaler were:

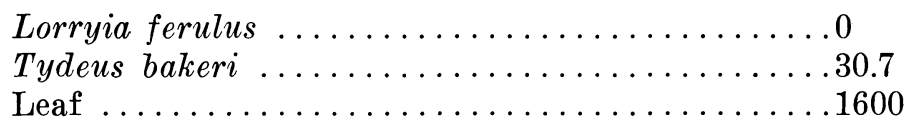

These results suggest that Tydeus bakeri takes up material from the plant cells. However, because of the relatively large surface of tydeids in relation to their volume, external contamination was possible.

With Coccid Eggs. When Saissetia hemisphaerica eggs were placed with 15 Tydeus bakeri adults, with no water available, 32 days elapsed before all adults died. No eggs were laid, perhaps because of the lack of favorable oviposition sites. Mites were seen crawling over the eggs and stopping, apparently in the act of feeding on the eggs. In tests with the same coccid eggs, in stender dishes, with water available, $20 \mathrm{~T}$. bakeri adults were placed on an abelia leaf floating in water. The last adult died after 26 days. Fourteen eggs were laid, but none of the hatched larvae developed to the nymphal stage. The chorion of the scale egg may be too thick for the chelicerae of the larvae. The larvae do not appear to attack eggs of their own kind, or at least do not obtain the necessary nutrients from cannibalistic behavior.

In a second test, 12 adults of each species were placed on an abelia leaf and 23 coccid eggs added. At the end of three weeks, three adults of Tydeus bakeri were still alive and two of Lorryia ferulus. The first species died out at the end of 30 days and the last adult of the latter species died after 32 days. Eggs were laid, presumably by both species, but they did not develop. A third test carried out on waxed paper was destroyed by fungus, the lid of the stender dish being closed. With L. ferulus in two further tests, a larva occasionally passed through to later stages. In the first test with 10 larvae, one molted to a protonymph and died, another became a deutonymph and died. Out of six larvae in another test, one formed a protonymph, and another a deutonymph; both died at these stages.

In all the above experiments, if an excessive hatching of scale eggs occurred, additional eggs were added to the substrate.

With European Red Mite Eggs. On walnuts, Lorryia ferulus was found in association with the European red mite, Panonychus ulmi (Koch). 
In the first test, 60 Tydeus bakeri adults were placed on an abelia leaf, and 25 European red mite eggs were added to the leaf. Kapok was placed on the leaf to obtain an even distribution of tydeid eggs and to promote oviposition more readily. Within 14 days, only 10 adults were alive, laying four eggs. As the spider mite eggs hatched, others were added. After 24 days the last adult tydeid died. A similar result was obtained using waxed paper. However, in this case the larvae proceeded to the adult stage, and these adults laid eggs. Later work revealed that this was due to honeydew flakes placed on the leaf when most of the adults had died.

One test was set up with Lorryia ferulus, using 10 adults and five host mite eggs. As the host eggs hatched, fresh eggs were added. Tydeid larvae appeared and the mites progressed to the adult stage, although half of the immature instars died. Three of six larvae reached the adult stage. The adequacy of these eggs as food was not comparable to honeydew discussed later in this paper. Tydeus bakeri in a concurrent test under the same conditions produced four eggs, of which two hatched but died as larvae.

In a confirmation test with Lorryia ferulus, using 10 adults initially, one egg hatched after 12 days, and within another week a dozen larvae appeared. After 35 days, a small colony developed with a dozen mites of all stages, a complete generation having been accomplished. Tydeus bakeri again gave a negative result, with no larvae proceeding to the protonymphal stage.

With Two-spotted Spider Mite Eggs. A test was set up with 10 adults of Lorryia ferulus and eight eggs of the two-spotted spider mite, Tetranychus telarius (Linnaeus). Because of the rapidity with which the host eggs hatched, it was necessary to supply fresh eggs to the waxed paper every third day. After 18 days, there were eight tydeid larvae present and a protonymph, and the adults were showing little mortality. After another week a small colony was forming rapidly, with many larvae, some protonymphs and deutonymphs. After 34 days, there was a sizable colony of $L$. ferulus containing all stages of mites. The population reached a peak of 30 mites of all stages competing for the host eggs in competition with a rapidly developing fungus, which was enveloping the eggs and substrate.

A test was set up with Tydeus bakeri at the same time under the same conditions as the above test. Two eggs of this species hatched in 12 days, and one mite progressed to the deutonymph. Further eggs laid by adults hatched, and 30 days after the test began, there were two protonymphs, a deutonymph and three adults left. Within another seven days a little colony was developing, with the deutonymph having gone through to an adult. Nearly two months after the test was initiated, a good colony of over 20 individuals in all stages was formed.

The above tests were repeated to confirm the results. After a month a colony was developing slowly with Lorryia ferulus. With Tydeus bakeri, some larvae proceeded to later stages after a month, but it was not possible to develop a colony as in the previous test; the later instar mites died except for one which became adult. All adults died a few days later.

Throughout the tests with two-spotted spider mite eggs, Lorryia ferulus 
showed response to their nutritional value and developed good colonies. Tydeus bakeri, however, developed only with difficulty and did not show the same response.

With Eriophyid Mite Adults. Because of the reports of the significance of eriophyid mites in the nutrition of certain species of tydeids, tests were carried out with adult eriophyids occurring on privet. The eriophyids were slightly crushed on the waxed paper substrate so that they would not wander off the substrate into the water in the dish. Additional eriophyids were supplied every three or four days.

With Lorryia ferulus seven larvae were produced from an initial group of 10 adults. After two weeks two of the immature stages were protonymphs. All the adults died after 38 days and the remaining larvae and protonymphs also died.

With Tydeus bakeri the last of 10 adults died after 24 days. One larva was produced which died.

It is apparent that eriophyid adults are not of nutritional importance to these two species of tydeids.

With Natural Honeydew. Honeydew is hygroseopic at high humidities and its nutrients become available in fluid condition. The honeydew used in these tests was obtained from eugenia leaves, being deposited by Saissetia hemisphaerica. Care was taken when selecting this excretion that no eggs or small larvae of the coccid were present on a flake of honeydew. The honeydew which becomes hard, supports a sooty mold fungus. There was no reference to honeydew as a mite nutrient when this study began, except for one reference by Huffaker and Kennett (1956), who found that two species of Typhlodromus receive part of their nutrients from aphid honeydew.

Tydeids were found to be always associated with honeydew on eugenia. Possibly this was due to the benefit to be derived from honeydew as an oviposition site, as a nesting situation, and a place to hide. However, tests show that honeydew is a complete nutrient for all stages of the two species of tydeids, and one on which they readily develop to a sizable colony.

Smirnoff (1957) states that a species of Lorryia in Morocco is attracted to sugar excretions of Saissetia oleae and feeds usually on honeydew.

In all cases of the test procedures, a colony developed rapidly with both species. These colonies were complete generations, with mites that had developed from eggs to adults on honeydew, then in turn laid eggs. It was not possible to keep colonies going for longer than two months because of fungus growth, unless mites were transferred to a fresh substrate.

In the first test with Lorryia ferulus, using 10 adults initially, within 22 days a colony of larvae, protonymphs and deutonymphs, was developing. At this time the colony was at the same stage of development as that of a two-spotted spider mite egg test colony under identical conditions. The colony developed rapidly and thrived, with a population of over 20 mites of all stages after one month of initiation of the test. The colony in another two weeks grew larger than the spider mite colony and then fungus enveloped it.

With Tydeus bakeri, using 10 adults initially, it took 17 days before a 
larva and two protonymphs were present to start a colony. In the case of the egg feeding tests being carried on at the same time, no tydeid eggs were laid. After 24 days elapsed the colony developed rapidly. It was kept going another month, developing continuously. The two-spotted spider mite test carried out similarly developed a good colony but always lagged behind that of the honeydew.

With Synthetic Honeydew. This diet was suggested by Hagen (1950). It consisted of three grams of enzymatic protein hydrolyzate of yeast plus six grams of fructose. He had developed this diet for increasing the fecundity of Chrysopa and various tephritids.

TABLE 1

SUMMARY OF NUTRITIONAL EXPERIMENTS

\begin{tabular}{|c|c|c|}
\hline \multirow{2}{*}{ Sources of nutrition } & \multicolumn{2}{|c|}{ Colony development } \\
\hline & Lorryia ferulus & Tydeus bakeri \\
\hline With leaves only & No development & No development \\
\hline With coccid eggs & $\begin{array}{l}\text { Development sometimes of larva to pro- } \\
\text { tonymph or to deutonymph }\end{array}$ & No development \\
\hline $\begin{array}{l}\text { With eriophyid mite } \\
\text { adults }\end{array}$ & $\begin{array}{l}\text { Development sometimes of larva to } \\
\text { protonymph }\end{array}$ & No development \\
\hline $\begin{array}{l}\text { With European red mite } \\
\text { eggs }\end{array}$ & $\begin{array}{l}\text { Using } 10 \text { adults initially, a colony devel- } \\
\text { oped with some difficulty, with a com- } \\
\text { plete generation in } 35 \text { days. }\end{array}$ & No development \\
\hline $\begin{array}{l}\text { With two-spotted spider } \\
\text { mite eggs }\end{array}$ & $\begin{array}{l}\text { Using } 10 \text { adults initially, a colony de- } \\
\text { veloped after } 25 \text { days, reaching a peak } \\
\text { of } 30 \text { individuals after one month. }\end{array}$ & $\begin{array}{l}\text { Using } 10 \text { adults initially, a colony devel- } \\
\text { oped after } 30 \text { days with } 20 \text { individuals } \\
\text { present after two months. Did not re- } \\
\text { spond as well as Lorryia ferulus. }\end{array}$ \\
\hline With natural honeydew & $\begin{array}{l}\text { Using } 10 \text { adults initially, a colony de- } \\
\text { veloped similarly to the other species } \\
\text { and maintained its vigor until con- } \\
\text { trolled by fungus. }\end{array}$ & $\begin{array}{l}\text { Using } 10 \text { adults initially, after } 24 \text { days a } \\
\text { colony was developing rapidly, which } \\
\text { kept developing vigorously, eventually } \\
\text { being controlled by fungus. }\end{array}$ \\
\hline $\begin{array}{l}\text { With synthetic honey- } \\
\text { dew }\end{array}$ & $\begin{array}{l}\text { Using } 10 \text { adults initially, a good colony } \\
\text { developed after } 23 \text { days, which con- } \\
\text { tinued vigorous development. }\end{array}$ & $\begin{array}{l}\text { Using } 10 \text { adults initially, slower develop- } \\
\text { ment of a colony than Lorryia ferulus. } \\
\text { A month before it began to develop. }\end{array}$ \\
\hline
\end{tabular}

The liquid synthetic honeydew was added with a dissecting needle, small drops being placed on the wax substrate. Three or four small drops were added every week. After a few days, the drop would support a strongly growing fungus.

Tests were carried out with each of the two species at the same time as the last of the egg feeding tests. With Lorryia ferulus, using 10 adults initially, after 23 days, a colony was developing on the synthetic honeydew, whereas with two-spotted spider mite eggs and in other tests there was not a similar rate of development. In this test there was no direct comparison with natural honeydew, but the synthetic material appeared to be as effective a nutrient as the nonsynthetic honeydew. 
Using 10 adults initially, Tydeus bakeri developed more slowly, and it was not until a month had elapsed that a colony began to build up, with comparative tests showing noticeably inferior results. Natural honeydew was not compared directly with the synthetic honeydew as a food source. However, the relative slowness of the latter was noticeable.

A summary of nutritional experiments is contained in Table 1.

\section{LIFE HISTORY STUDIES}

Because of the small size of the early stages, and the way in which the tydeids hid under honeydew, under the splinters of wood, or under mycelial strands of fungus, it was difficult to follow the development of the various stages.

During these observations, temperature varied from just under $20^{\circ} \mathrm{C}$ to $28^{\circ} \mathrm{C}$. Approximate periods of the various stages are given.

The female lays as many as four eggs at a time, close together. The eggs of both species are pearly white and shiny, approximately $140 \mu$ long and $80 \mu$ wide. The eggs of Tydeus bakeri hateh seven to eight days after laying, while those of Lorryia ferulus hatch in six to seven days.

Tests were made on the significance of oviposition sites on waxed paper. It was found that an oviposition site such as a splinter of boxwood, or kapok, increased the number of eggs laid from two to four times. For example, tests showed that if adults were on a substrate containing no site, three eggs might be laid, whereas on a substrate under identical conditions but with a site, from seven to twelve eggs could be expected on the average. The female lays the egg in a normal position with her dorsal surface uppermost; but on one occasion a female was observed lying on her back with the anterior portion of the body curved into the air while the egg was extruded from the genital opening.

The six-legged larva, on hatching, settles down under cover near the oviposition site, whether it be under a scale, under a flake of honeydew, or at the corner of two veins among the leaf hairs. It is likely to become part of a colony nesting in one of these positions, moving out to feed. With Lorryia ferulus the larval period lasts three to four days; with the other species it lasts four days. Molting occurs in the nesting site, where large numbers of cast skins usually can be seen. The larval stage has no genital or aggenital setae (figures $1 \mathrm{~B}, 2 \mathrm{~A}$ ).

The protonymph stage lasts seven to ten days with Tydeus bakeri and six to eight days with the other species. The nymphs are characterized by the development of genital and aggenital setae. The protonymphs of both species have one pair of genital setae, but they are distinct from the later stages in that aggenital setae are not present (figures 1D, 2B).

The deutonymph and tritonymph stages of Lorryia ferulus last 10 to 12 days and there is a period of 11 to 14 days until the adult stage is reached. The deutonymph stage in both species is similar, with the development of two pairs of genital setae and two pairs of aggenital setae (figures 1C, 2C). The tritonymph has four pairs of genital setae and four pairs of aggenital setae (figures $1 \mathrm{~A}, 3 \mathrm{~A}, 3 \mathrm{~B}$ ). 

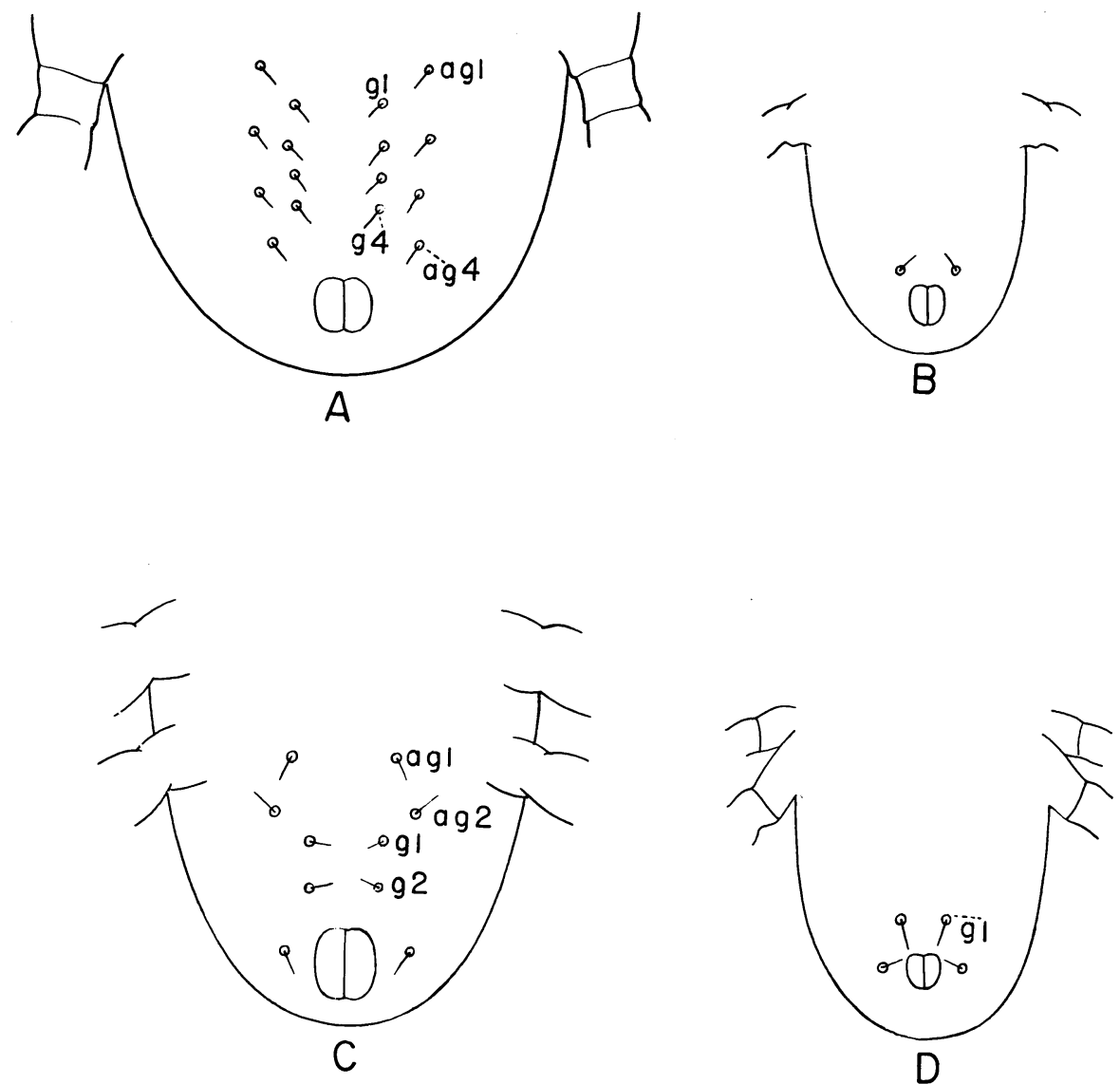

Fig. 1. Lorryia ferulus: Venter of opisthosoma of A, tritonymph; B, larva; C, deutonymph; D, protonymph: g. genital seta; ag. aggenital seta. 

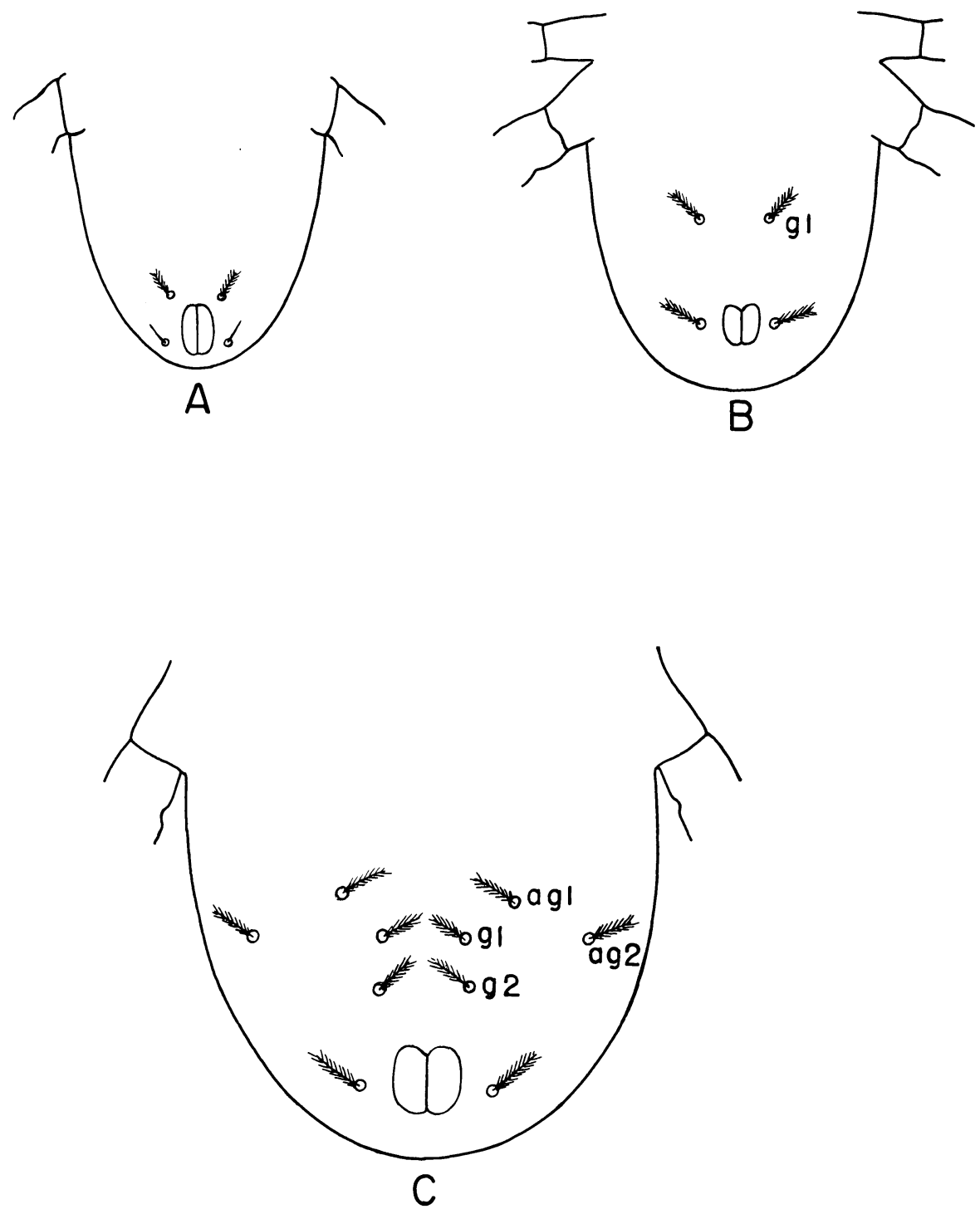

Fig. 2. Tydeus bakeri: Venter of opisthosoma of A, larva; B, protonymph; C, deutonymph: g. genital seta; ag. aggenital seta. 

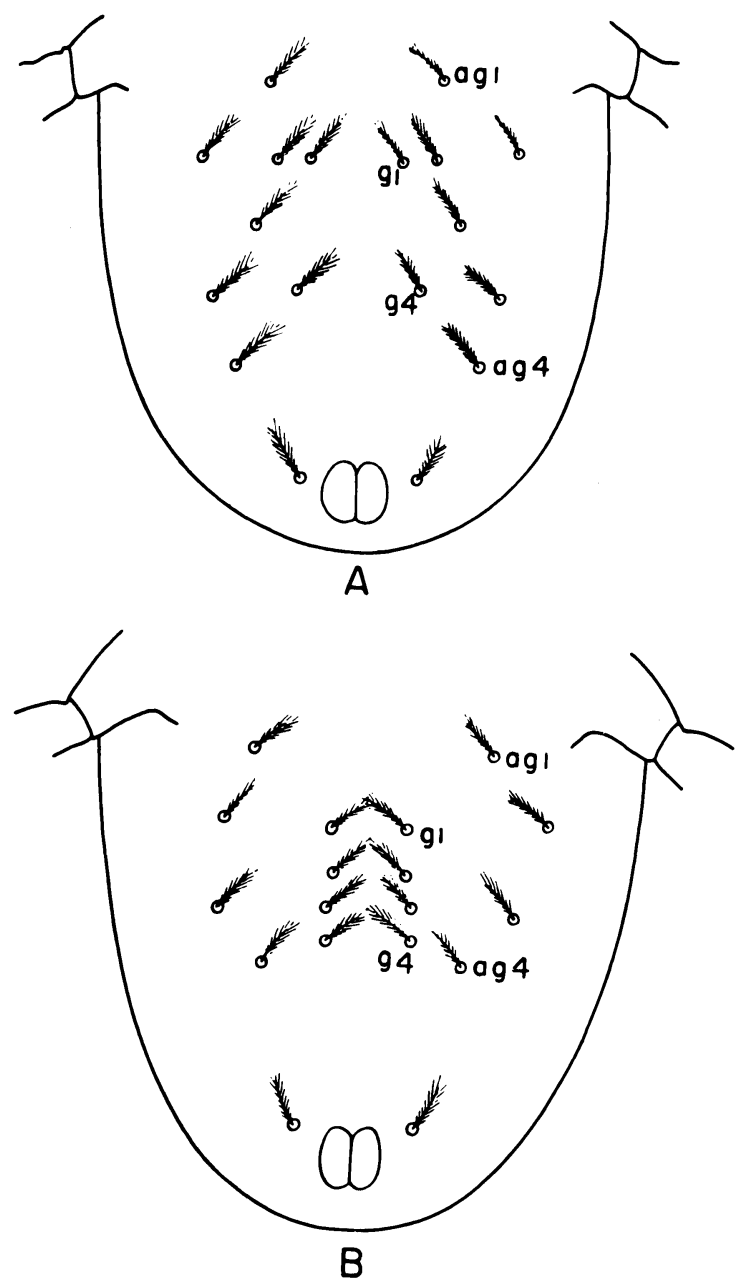

Fig. 3. Tydeus bakeri: Venter of opisthosoma of A, B, tritonymphs: g. genital seta; ag. aggenital seta. 
October, 1958]

Brickhill: Two Species Tydeid Mites

613
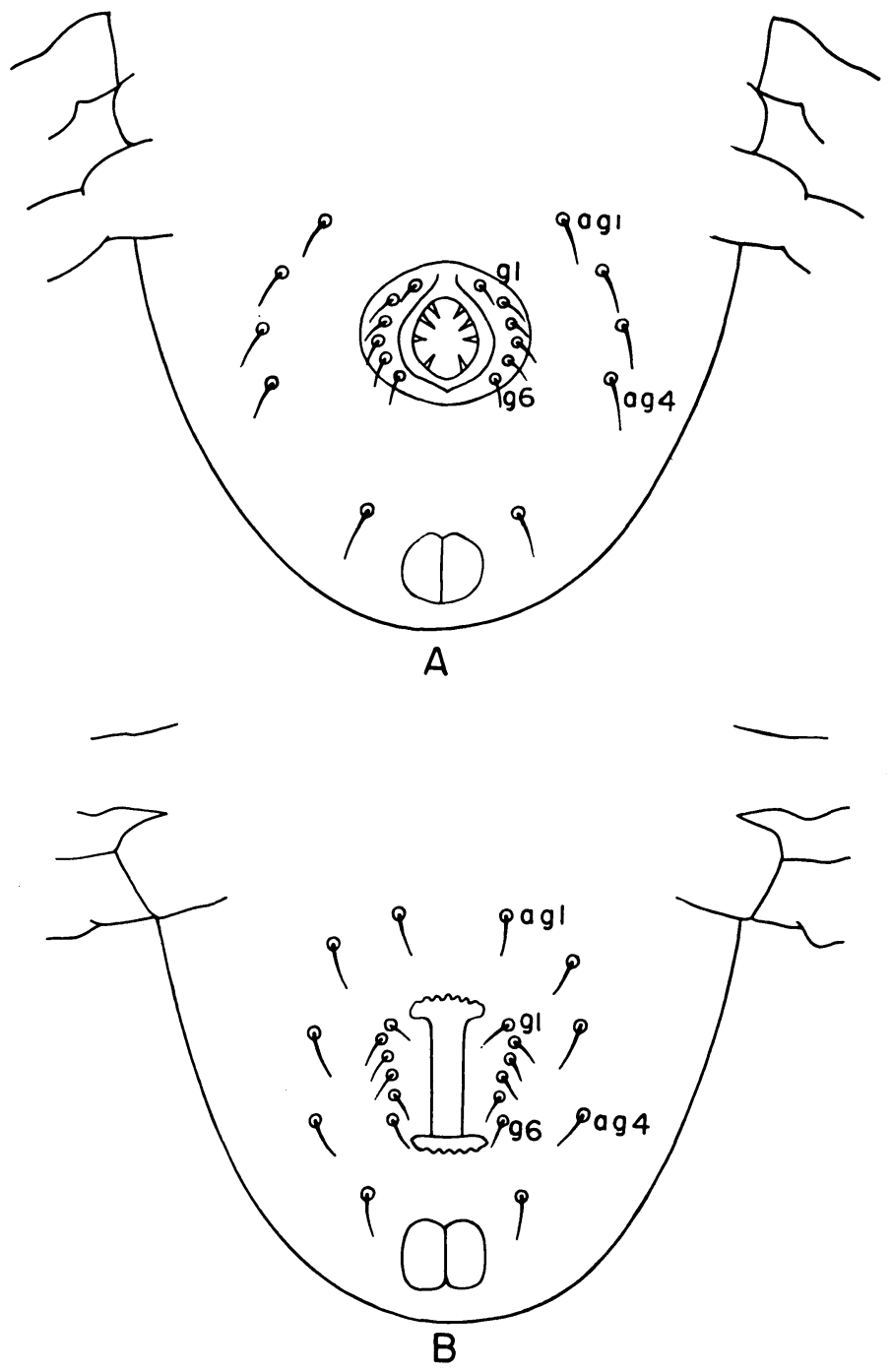

Fig. 4. Lorryia ferulus: Venter of opisthosoma of adults; A, male; B, female: g. genital seta; ag. aggenital seta. 

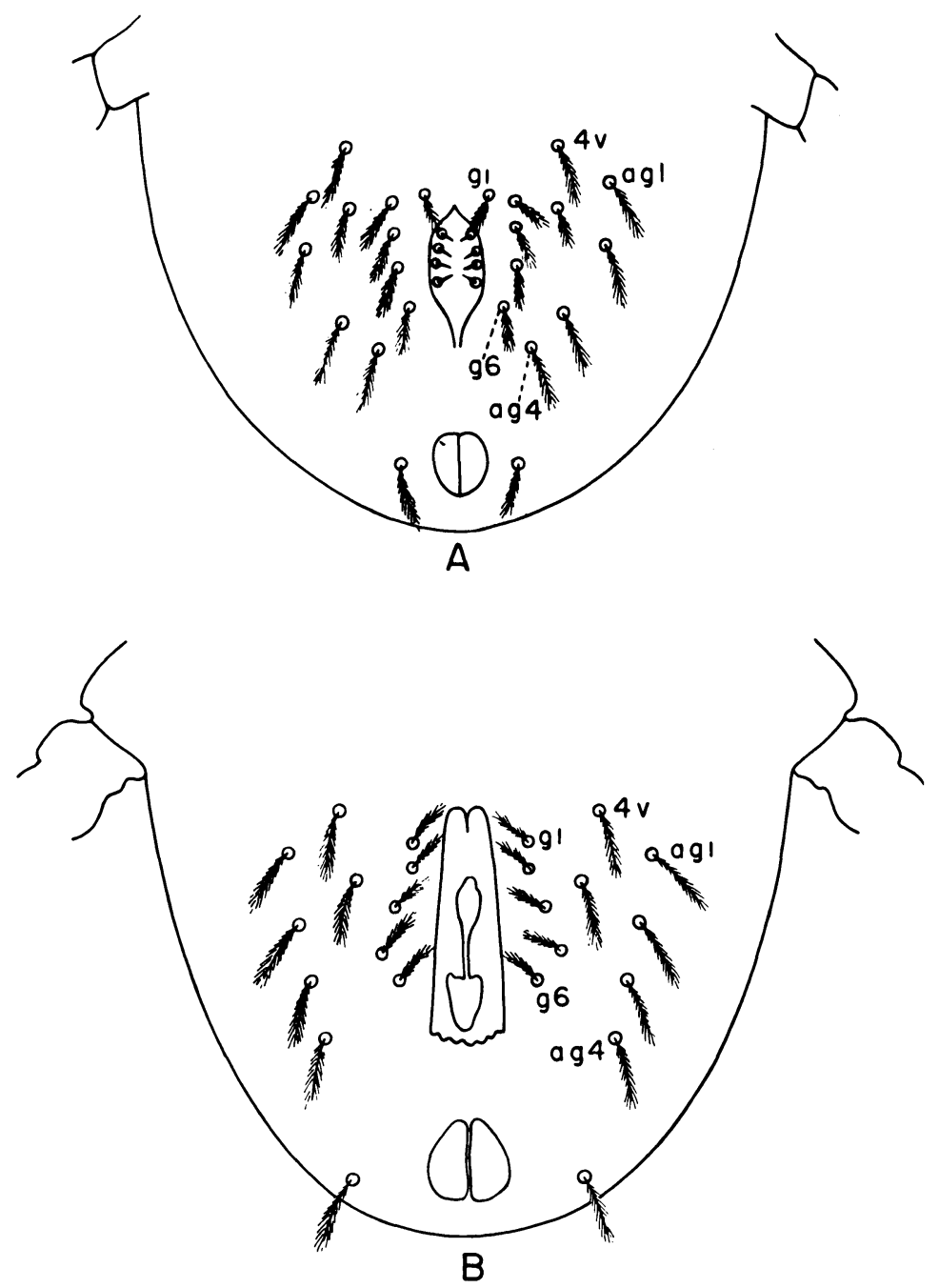

Fig. 5. Tydeus bakeri: Venter of opisthosoma of adults; A, male; B, female: g. genital seta; ag. aggenital seta; v. ventral seta outside genital area. 


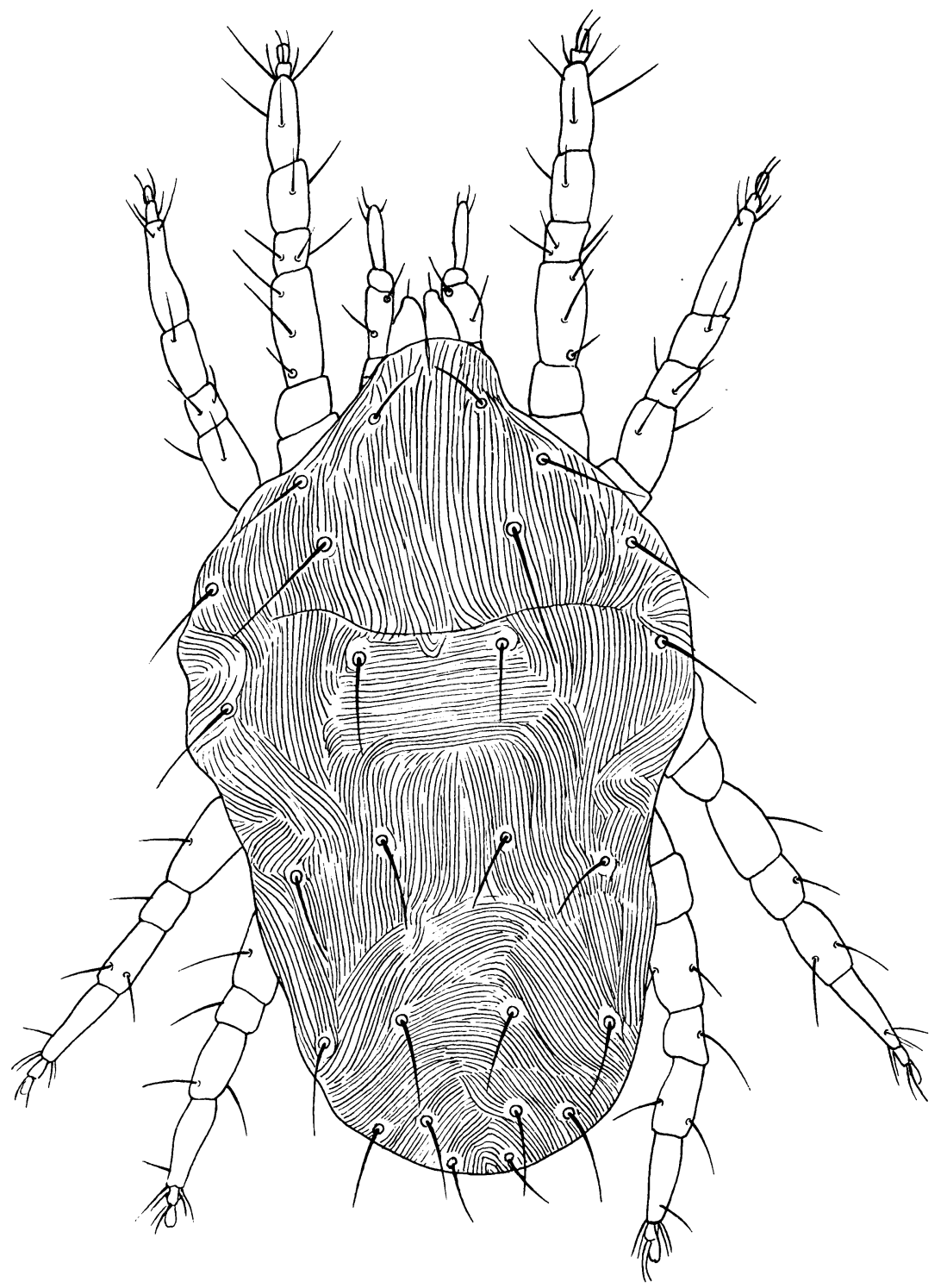

Fig. 6. Lorryia ferulus: Dorsal view of male showing pattern of striae. 


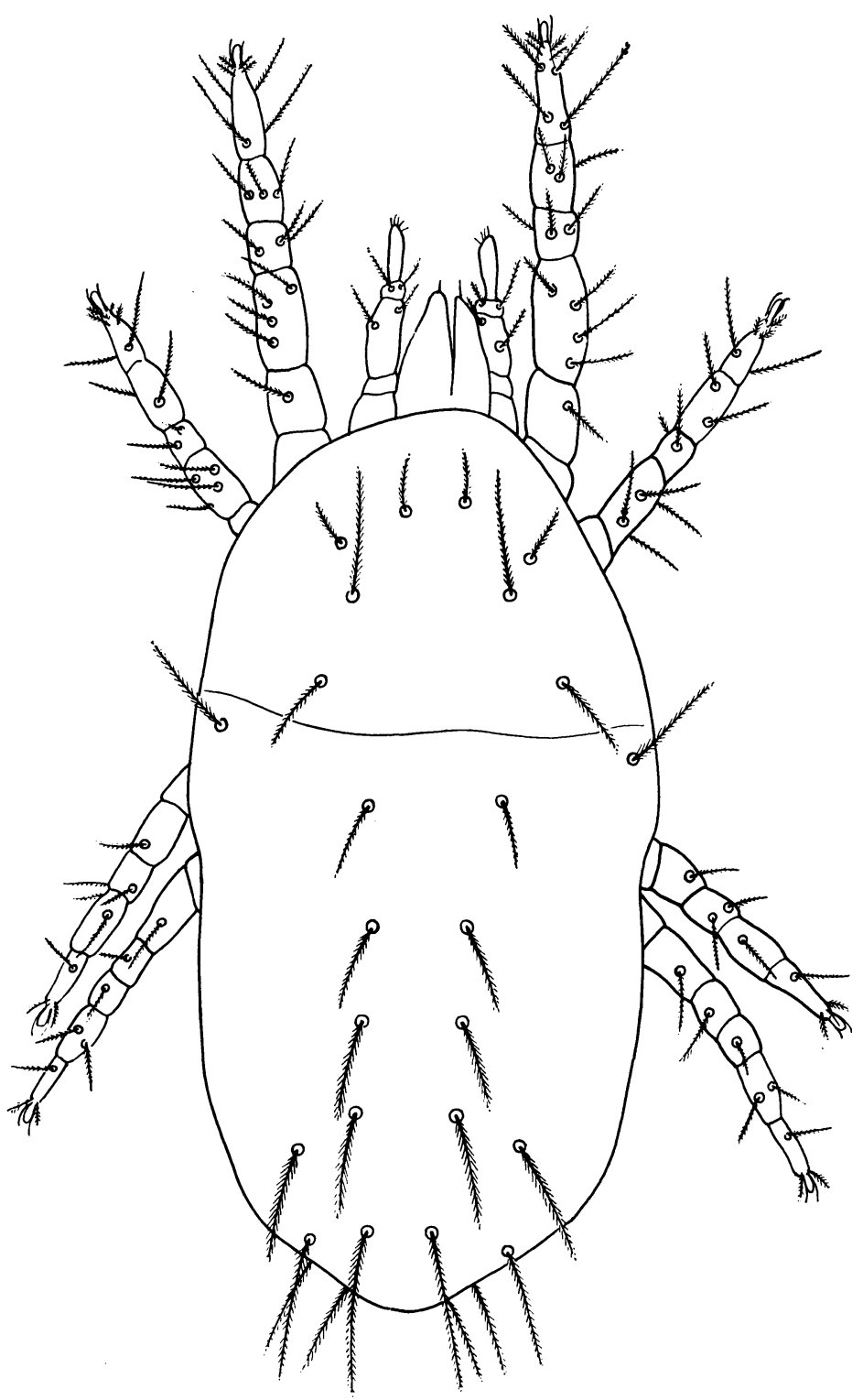

Fig. 7. Tydeus bakeri n. sp.: Dorsal view of female. 
The sexes cannot be distinguished until the last molt, when the genital opening is differentiated. It is simple to distinguish the sexes because of the presence of eugenital setae in the male. The shapes of the genital areas are distinctive. The genital and the aggenital setae are the same in both sexes. There are six pairs of genital setae and four pairs of aggenital setae in the adults (figures 4 and 5). The genital area is long and relatively thin in the female, while in the male it is of triangular pattern, shorter and wider than in the female. Both these species follow the same pattern in chaetotaxy for the final stages as described by Grandjean (1938) for tydeids.

The adults begin oviposition three or four days after the last molt, the complete life cycles at the room temperatures being approximately 32 to 38 days with Tydeus bakeri and 30 to 34 days with Lorryia ferulus.

\section{DISCUSSION}

An outstanding feature of the studies was the revelation of the importance of honeydew in nutrition of both species of tydeids. This result was unexpected. It was considered that the studies would reveal a close nutritive relationship with scale or other mite eggs, with some evidence possibly of a phytophagous nutritive relationship. The value of honeydew was demonstrated clearly whenever it was used. Although on one or two occasions a colony was slow in developing, one could have confidence that eventually a strong colony would be produced until it became enveloped by fungus, which flourished on the honeydew. The humidity over the substrate was necessarily high, but this could not be avoided without changing the technique of the experiments completely. Tydeids are not easy to work with, being very susceptible to mechanical injury, and their small size is a disadvantage. They are not profuse egg producers, as are spider mites, and populations do not develop with the speed of such mites. However, it was not necessary to use any technique in the tests beyond the one developed, as it suitably demonstrated the capacity of a nutrient to take the tydeids through a complete generation and to build up a colony. If it were considered necessary to continue the colony, all that would be necessary would be to transfer the mites individually as carefully as possible to a fresh substrate in a new stender dish.

No reference has been seen in the literature of mites having been bred through all their stages of development on a diet of honeydew, although, as stated previously, honeydew has been shown to be part of the nutrition of two species of Typhlodromus.

Of further interest is the ease with which colonies were developed on Hagen's synthetic honeydew. This appeared to be just as effective as the natural honeydew, except possibly with Tydeus bakeri.

Two-spotted spider mite eggs proved to be a good nutrient for Lorryia ferulus, which may be related to the development of their colonies on strawberries. However, the significance of aphid honeydew is not known on this crop; it is common on strawberry plants and could be an effective nutrient. Tydeus bakeri did not show the same response to two-spotted 
spider mite eggs. This species was never found in the field in association with these spider mite eggs.

The behavior of the two species with European red mite eggs also appears to correlate with field association. These eggs do not appear to be as effective a nutrient as two-spotted spider mite eggs for Lorryia ferulus, which were comparable to honeydew. However, the European red mite eggs appeared to be effective enough to tide $L$. ferulus over a period when honeydew was not available, although it was not demonstrated that they would serve to build up a large colony. In the field, Lorryia colonies were scattered over the orchards and on some occasions were large on some leaves. Associated concentrations of honeydew were light compared to the concentration seen on eugenia.

The lack of a positive result with European red mite eggs serving as a nutrient for Tydeus bakeri is interesting, since this species and these eggs have never been observed together in the field.

The poor result with coccid eggs may be due purely to a mechanical inability of the larvae to penetrate readily the thick chorion. In any case it does not appear that these eggs are an important source of food, as honeydew is such a good food and is readily available to the mites. However, it is of interest that Tydeus bakeri when placed with coccid eggs in the absence of water lived for a month as compared with two to four days when eggs or water were not available. This suggests the adults were able to penetrate the chorion, and they were seen apparently in the act of piercing the egg. In the case of Lorryia ferulus occasionally one of the larvae was able to develop to a protonymph, suggesting they were able to penetrate the chorion and obtain nutrients.

The results in the laboratory tests with leaves seemed conclusive with both species, although the test with radioactive glycine $-2 \mathrm{C}^{14}$ conflicts in the case of Tydeus bakeri. It could be that this species pierces the cells but cannot obtain the nutrients necessary for its continued development. Or surface contamination could be the factor giving a misleading result. The breaking of a hair or accidental bruising of leaf cells could have released radioactive material which became attached to the mite externally as it passed over it. Overall, the evidence is positive that these species of tydeids do not obtain essential nutrients phytophagously.

Concerning the possible economic importance of these mites, it appears that they are of no importance to their plant hosts directly. They may be of minor importance as predators on scale eggs, but on the other hand, the evidence is that the eggs hatch even if they have been fed upon. This was especially noticeable with two-spotted spider mite eggs, which were such a good nutritive source for Lorryia ferulus. Despite the fact that a diet of these eggs bred thriving colonies, the hatch of spider mites was close to 100 per cent.

\section{Tydeus bakeri n. sp.}

The subclavate fifth palpal segment of Tydeus bakeri will readily differentiate it from other known species in the genus.

Body elongate oval, pale flesh-colored. Length $200 \mu$, greatest width $130 \mu$. Idiosoma rounded anteriorly and posteriorly. Furrow between propodosoma 
and hysterosoma, extending to lateral margins. Integument soft with very fine transverse striae. Setation of idiosoma distinctly plumose compared to weakly plumose setation of palpi and legs. Propodosoma with three pairs of marginal setae of equal length and one pair of long sensory setae. Hysterosoma with one pair of lateral setae immediately posterior to furrow, five pairs of dorso central setae, two pairs of lateral setae in line transversely with last two pairs of dorso central setae. Palpus with five segments, the second and fourth segments short, the third segment three to four times as long as wide, the fifth segment four times as long as wide with outer margin nearly straight and the inner margin slightly swollen; the third and fourth segments each with two setae. Legs stout; tarsi with two claws and empodium. Leg I trochanter with one seta; femur nearly three times as long as wide, with four setae; trapezoidal genu with three setae; tibia twice as long as wide, with three setae, tarsus with four long and four short setae. Leg II femur twice as long as wide with four setae; genu as long as wide with two setae; tibia twice as long as wide with two setae, and tarsus with four short and two long setae. Leg III with one seta on femur, two setae on genu, one seta on tibia, and one long and three short setae on tarsus. Leg IV with one seta on each of segments two, three, and four, two on tibia, and one long and three short on tarsus.

Holotype. Female, Albany, California, April 4, 1957 (C. D. Brickhill), on eugenia; type no. 2464 in the U. S. National Museum.

Paratypes. Two females, four males, Albany, California, April 4, 1957 (C. D. Brickhill), on eugenia; one female, Albany, California, February 16, 1957 (C. D. Brickhill), on eugenia.

This species is named in honor of Dr. E. W. Baker.

\section{SUMMARY}

1. A study was made on the biology of two species of tydeids found in central California, with emphasis on their nutrition. These were Lorryia ferulus Baker and Tydeus bakeri $\mathrm{n}$. sp.; the former species was found on a wide variety of hosts usually in association with coccid scales and sometimes with European red mites or two-spotted spider mites, while the latter species was found only on eugenia in association with a coccid scale.

2. Both species were found in colonies on leaves or twigs, nesting under scales or honeydew or among leaf hairs. All stages were found throughout the year, with populations lowest in winter and summer.

3. The tydeids were collected by direct transfer under microscopes from leaf or twig by means of a brush and transferred to the rearing substrate. Nutrition tests were carried out using as a substrate either a leaf or waxed paper floating in water in a stender dish. The nutrient being tested was then added to the substrate. An oviposition site was necessary.

4. Neither species showed any nutritional response to host leaves. However, in a test using radioactive glycine $-2 \mathrm{C}^{14}$ a significant Tracerlab $\mathrm{SC}-1 \mathrm{C}$ Autoscaler reading above background was obtained with Tydeus bakeri, which may have been due to external contamination.

5. With coccid scale eggs, only Lorryia ferulus showed a developmental response, which was weak, with no nymphs developing to adults. With 
European red mite eggs, only L. ferulus responded, and could be reared only with some difficulty. With two-spotted spider mite eggs, both species could be reared readily, with $L$. ferulus more responsive. With eriophyid mite adults, $L$. ferulus responded slightly but could not be reared. The other species did not respond.

6 . Both species could be reared readily on natural honeydew. On a synthetic honeydew of enzymatic protein hydrolyzate of yeast plus fructose, developed by Hagen, both species could be reared with Lorryia ferulus developing more readily than the other species.

7. At $20^{\circ}$ to $28^{\circ} \mathrm{C}$ the approximate lengths of the life cycles were 32 to 38 days for Tydeus bakeri and 30 to 34 days for Lorryia ferulus. Both species have six stages, including a tritonymph. These stages can be distinguished by differences in the number of pairs of genital and aggenital setae. The male may be recognized by the eugenital setae and by the shape of the genital area.

8. Tydeus bakeri n. sp. is described.

\section{ACKNOWLEDGMENTS}

Acknowledgment is made to Dr. A. E. Pritchard, for advice during these studies and aid in preparation of the article; to Drs. D. P. Furman and C. H. Hand for advice on the manuscript; to Miss Celeste Green for aid with the drawings; to Drs. W. M. Hoskins and H. T. Gordon, and Mr. W. R. Erwin for aid with radioactive studies; to Dr. K. S. Hagen for aid with synthetic honeydew studies, and to Mr. G. L. Finney for kapok which was tried as an ovipositional site.

\section{LITERATURE CITED}

BAKER, E. W., and G. W. WharToN

1952. An introduction to acarology. The Macmillan Co., New York. Pp. 190-93.

Finney, G. L.

1953. A technique for mass-culture of the six-spotted mite. Jour. Econ. Ent. 46(4): $712-13$.

Fleschner, C. A., and K. Y. Arakawa

1953. The mite Tydeus californicus on citrus and avocado leaves. Jour. Econ. Ent. $45(6): 1092$.

GrandJean, F.

1938. Observations sur les Tydeidae. Bul. Mus. Nat. d'Histoire Naturelle 2e Serie-Tome $\mathbf{X}(4): 377-84$.

HAGEN, K. S.

1950. Fecundity of Chrysopa californica as affected by synthetic foods. Jour. Econ. Ent. 43 (1) : 101-04.

HUFFAKER, C. B. and C. E. KENNETT

1956. Experimental studies on predation. Predation and cyclamen-mite populations on strawberries in California. Hilgardia 26(4) :191-222.

McGregor, E. A.

1932. The ubiquitous mite, a new species on citrus. Ent. Soc. Wash. Proc. 34(4) :60-61.

SMIRNOFF, W. A.

1957. An undescribed species of Lorryia (Acarina, Tydeidae) causing injury to citrus trees in Morocco. Jour. Econ. Ent. 50 (3):361-62. 
The journal Hilgardia is published at irregular intervals in volumes of about 600 pages. The number of issues per volume varies.

Subscriptions are not sold. The periodical is sent as published only to libraries, or to institutions in foreign countries having publications to offer in exchange.

You may obtain a single copy of any issue free, as long as the supply lasts; please request by volume and issue number from:

\section{Agricultural Publications \\ Room 22, Giannini Hall \\ University of California \\ Berkeley 4, California}

The limit to nonresidents of California is 10 separate issues on a single order. A list of the issues still available will be sent on request. 
